\title{
AGGLUTININS AND INCOMPLETE ANTIBODIES AFTER A SINGLE ANTIGENIC INOCULATION IN NORMAL AND RHEUMATIC INDIVIDUALS
}

\author{
BY \\ VLADIMÍR WAGNER AND VÁCLAV REJHOLEC \\ From the Institute of Medical Microbiology and Immunology, Plzen, \\ and the Research Institute for Rheumatic Diseases, Prague \\ With statistical collaboration by \\ VLADIMIR MaĹ் \\ Institute of Sanitary Organization, Prague \\ and technical collaboration by \\ E. Hallero'a, M. Motliková, and M. Repič-Š́lechta
}

(RECEIVED FOR PUBLICATION MARCH 22, 1955)

It is well known that elevated levels of antibodies against various antigens of Group A pyogenic streptococci are found in rheumatic fever (Harris, 1948; Rantz and others, 1951). This phenomenon may be due to the increased immunologic reactivity of the macro-organism, to repeated natural infection by the micro-organism, or to the persistence of the micro-organism in the body of the host longer than in normal individuals. Several authors have already tried to establish that rheumatic subjects develop more antibodies than normal persons, even to antigens other than streptococcal.

Creger, Choy, and Rantz (1951) found that patients with diseases in which immunologic pathogenesis is presumed produce antibodies in higher titres than controls, but their tests have the disadvantage of small numbers. Miller, Kibrick, and Massell (1953) found in rheumatic subjects only a slight elevation of titres after immunization in comparison with controls. They inferred that rheumatic fever cannot be explained by hyperreactivity. Quinn, Seastone, and Dickie (1953) immunized a restricted number of rheumatic subjects and controls with pneumococcus polysaccharides and measured the antibodies by quantitative precipitation. They found no substantial difference between the two groups.

Other authors have shown the importance of incomplete antibodies in allergy (Coca and Grove, 1925; Miller and Campbell, 1947; Campbell and others, 1950; Sherman and others, 1950; Marrack, 1951; Kuhns and Pappenheimer, 1952); many regard allergy as a pre-eminent factor in the development of rheumatism (Weintraud, 1913; Klinge,
1933; Talalajew, 1933, 1936; Rössle, 1933; Albertini and Grumbach, 1933; Alpern, 1934; Aikawa, 1945).

In the present investigation the immunological reactivity of rheumatic subjects was examined by studying the levels of complete and incomplete antibodies after a single administration of nonstreptococcal antigens. A group of individuals past the acute stage of rheumatism and an adequate control group were immunized with the Brucella abortus.

\section{Material}

In 1952-53, a large hostel for apprentices in Bohemia was affected by a streptococcal epidemic accompanied by a high incidence of rheumatic fever. In the period of a few months, scores of apprentices fell ill with this disease, and most of the patients were admitted to hospital. Those to be tested were chosen according to the data given by the hospital.

The rheumatic subjects numbered 42 (23 boys and nineteen girls) with an average age of 16 years $(88.4$ per cent. were just 16 , four were 17 or 18 , and one was 15 ). They had all had acute rheumatism: $24(57 \cdot 1$ per cent.) not more than 1 year before, twelve $(28.5$ per cent.) 1 to 2 years before, and six more than 2 but less than 7 years before. Ten (23.8 per cent.) had had more than one attack of the disease.

All the rheumatic subjects were examined thoroughly for signs of persistence of sequelae of the disease. In eight (19 per cent.) conditions due to a past rheumatic endocarditis with valvular defects were found. At the time of the examination, none had an erythrocyte sedimentation rate higher than $10 \mathrm{~mm}$./hr. No other symptoms of activity of the disease were present at the time of the immunization procedure.

The control group consisted of 51 apprentices of the same school, all from the same class and all 16 years old. 
They were clinically examined for signs of any previous rheumatic disease and for brucellosis. This investigation was negative in all cases. None of the controls showed any symptoms of cardiac abnormality.

Before immunization, blood samples were examined for the presence of anti-brucella complete and incomplete antibodies. In all cases the result was negative. On the same day, all subjects were injected subcutaneously in the left arm with $0.5 \mathrm{ml}$. brucella bacteria. No reactions were observed either immediately or later. Blood samples for serological examination were taken on the 5th, 9th, 14th, and 19th days after immunization, and were examined within 2 days. In the course of the experiments, no rheumatic or control subjects contracted intercurrent disease, and no case of activation of rheumatism occurred.

\section{Methods}

Medium for Brucella abortus Culture.- 500 gr. crushed bovine liver were put into $1,000 \mathrm{ml}$. water, boiled for $2 \mathrm{hrs}$ on a low flame, and then filtered through paper. Water was added up to the original volume. $20 \mathrm{gr}$. peptone and 5 gr. salt were added and the solution was slightly alkalinized $(7 \cdot 2)$. Then 20 gr. washed agar weed were dissolved in the liquid, and the suspension was sterilized at $115^{\circ} \mathrm{C}$. for $30 \mathrm{~min}$. Non-filtered medium was put into Colle tubes, and sterilized for another $20 \mathrm{~min}$. The final $p \mathrm{H}$ was usually 6.6 to $6 \cdot 8$.

Antigen.-A strain of Brucella abortus* was used and inoculated into oblique agar. After a 24-hr growth at $37^{\circ}$ C., this was washed with Ringer solution, and the suspension was transferred to the surface of the liver agar in a number of tubes. After incubation at $37^{\circ} \mathrm{C}$. for $48 \mathrm{hrs}$ the culture was washed with a small quantity of Ringer solution with 0.002 per cent. merthiolate. The suspension was heated to $60^{\circ} \mathrm{C}$. for $30 \mathrm{~min}$., diluted according to the McFarland scale No. 4, put into small vessels for blood conservation $(100 \mathrm{ml}$.), and fastened with a rubber and metallic enclosure. Then samples were taken with sterile syringes and needles for testing sterility and toxicity. Sterility was tested on several liver media with thioglycolate $(0.5$ per cent.) under aerobic and anaerobic conditions for 5 days. Toxicity was tested on three mice inoculated intraperitoneally with $0.2 \mathrm{ml}$., $0.3 \mathrm{ml}$., and $0.5 \mathrm{ml}$. of the suspension respectively. The animals showed no symptoms of the disease for 14 days.

Serological Tests.-Serum was diluted with Ringer solution in geometric progression from 1.4 to 1.2048 in agglutination test tubes of $0.25 \mathrm{ml}$. each. To every dilution of the serum was added $2 \cdot 25 \mathrm{ml}$. Brucella abortus suspension prepared in the same manner as for immunization but diluted according to McFarland scale No. 2. After mixing, it was incubated in a water bath at $45^{\circ} \mathrm{C}$. for $18 \mathrm{hrs}$. Agglutinations were read with the naked eye against a dark background in oblique light while the test tubes were slowly rotated. The first and the last tube showing globular agglutination were recorded as the limits of the positive titre. All test tubes

* Furnished by the courtesy of Dr. John, Charles University, Institute of Medical Microbiology. with a negative reaction were tested for incomplete antibodies, using the antiglobulin serum (Coombs, Mour ant, and Race, 1945). The test tubes were centrifuged and the liquids poured off. Ringer solution was liberalfy added, and the sediment was resuspended and recentr: fuged. This process was repeated four times. Finally the sediment was resuspended in $0.25 \mathrm{ml}$. serum againgt human globulin, diluted by Ringer solution so as to. obtain in the solution twice the quantity of its final titre?

The potency of the serum was measured by collodial agglutination with human gamma globulin. $\dagger$ This process was also carried out with a negative serum, for purposes of control. The suspension was then inces bated at $45^{\circ} \mathrm{C}$. for one hour and read. The sediment was shaken.

A homogeneous suspension was recorded as a negative result. Positive agglutinations now and then showed rather small globules, and the results were therefore reat with a low-power agglutinoscope.

As only the test tubes with negative reaction could be tested for incomplete antibodies, the question arose hotb to evaluate incomplete antibodies in the test tubes with positive reaction, i.e. showing globular agglutination. Here, incomplete antibodies may be present in the samge quantities as normal agglutinins, or in smaller quang tities, or may be missing altogether. With existint methods this cannot be ascertained. These cases were evaluated as if incomplete antibodies occurred in the up to the titre of normal antibodies. This valuation is explained below.

\section{Results}

No agglutinins were found in the sera of investigated subject taken on the 5th day after immunization. Incomplete antibodies were found in two controls and seventeen rheumatic subjecto but in low titres only, the maximum being $1 \cdot 12$ On the ninth day agglutinins appeared in the sera ब six controls and ten rheumatic subjects, and incomplete antibodies in fifteen controls and nineteef rheumatic subjects. The number of reacting subjects in these two tests was too small to be used fof reliable statistical comparison. Therefore only the results obtained from the reactions of sera take 14 and 19 days after immunization were compared.

The results of the examination of samples collected after 14 and 19 days appear in Table I, which showe that after 14 days nine rheumatic persons $(21.4$ per cent. of 42) showed no agglutinins, whilst the remaino ing 33 (78.6 per cent.) produced agglutinins up tơ titre $1 \cdot 8$, as well as up to titre $1 \cdot 16$ and even $1 \cdot 32$ in titre 1.64 there were not more than 28 positive cases (66.7 per cent.). To take another instances examination for incomplete antibodies of sampleg taken after 19 days show eight negative cases out of fifty controls (16 per cent.) and none in the rheumatio group; in titre 1.8 there are 42 positive contros

\footnotetext{
† For technique see Wagner (1954).
} 
TABLE I

BASIC DATA OBTAINED IN TESTS

Numbers given in this Table serve to compute values appearing in Tables II and III, as described in the text

\begin{tabular}{|c|c|c|c|c|c|c|c|c|c|c|c|c|c|c|c|c|c|c|}
\hline \multicolumn{3}{|c|}{$\begin{array}{c}\text { Blood Samples taken } \\
\text { after } \quad \ldots\end{array}$} & \multicolumn{8}{|c|}{14 Days } & \multicolumn{8}{|c|}{19 Days } \\
\hline \multirow[t]{3}{*}{ Group } & \multirow{3}{*}{\multicolumn{2}{|c|}{. }} & \multicolumn{4}{|c|}{ Control } & \multicolumn{4}{|c|}{ Rheumatic } & \multicolumn{4}{|c|}{ Control } & \multicolumn{4}{|c|}{ Rheumatic } \\
\hline & & & \multicolumn{2}{|c|}{$\boldsymbol{A}$} & \multicolumn{2}{|c|}{$I A$} & \multicolumn{2}{|c|}{$A$} & \multicolumn{2}{|c|}{$I A$} & \multicolumn{2}{|c|}{$A$} & \multicolumn{2}{|c|}{$I A$} & \multicolumn{2}{|c|}{$A$} & \multicolumn{2}{|c|}{$I A$} \\
\hline & & & abs. & $\begin{array}{c}\text { per } \\
\text { cent. }\end{array}$ & abs. & $\begin{array}{c}\text { per } \\
\text { cent. }\end{array}$ & abs. & $\begin{array}{c}\text { per } \\
\text { cent. }\end{array}$ & abs. & $\begin{array}{l}\text { per } \\
\text { cent. }\end{array}$ & abs. & $\begin{array}{c}\text { per } \\
\text { cent. }\end{array}$ & abs. & $\begin{array}{c}\text { per } \\
\text { cent. }\end{array}$ & abs. & $\begin{array}{c}\text { per } \\
\text { cent. }\end{array}$ & abs. & $\begin{array}{c}\text { per } \\
\text { cent. }\end{array}$ \\
\hline \multicolumn{3}{|c|}{ Total Cases } & 51 & & 51 & & 42 & & 42 & & 50 & & 50 & & 41 & & 41 & \\
\hline \multicolumn{3}{|c|}{ Negative Cases } & 29 & $56 \cdot 9$ & 20 & $39 \cdot 2$ & 9 & $21 \cdot 4$ & 0 & 0.0 & 25 & $50 \cdot 0$ & 8 & $16 \cdot 0$ & 3 & $7 \cdot 3$ & 0 & $0 \cdot 0$ \\
\hline $\begin{array}{l}\text { Positive } \\
\text { Cases } \\
\text { up to } \\
\text { Titre }\end{array}$ & & $\begin{array}{r}8 \\
16 \\
32 \\
64 \\
128 \\
256 \\
512 \\
, 024 \\
, 048 \\
, 096 \\
3,192\end{array}$ & $\begin{array}{r}22 \\
22 \\
21 \\
18 \\
9 \\
4 \\
2 \\
1 \\
0 \\
0 \\
0\end{array}$ & $\begin{array}{r}43 \cdot 1 \\
43 \cdot 1 \\
41 \cdot 2 \\
35 \cdot 3 \\
17 \cdot 6 \\
7 \cdot 8 \\
3.9 \\
2.0 \\
- \\
-\end{array}$ & $\begin{array}{r}31 \\
30 \\
28 \\
26 \\
15 \\
10 \\
8 \\
1 \\
0 \\
0 \\
0\end{array}$ & $\begin{array}{c}60.8 \\
58.8 \\
54.9 \\
51.0 \\
29.4 \\
19.6 \\
15.7 \\
2.0 \\
- \\
-\end{array}$ & $\begin{array}{r}33 \\
33 \\
33 \\
28 \\
22 \\
14 \\
8 \\
0 \\
0 \\
0 \\
0\end{array}$ & $\begin{array}{c}78 \cdot 6 \\
78 \cdot 6 \\
78 \cdot 6 \\
66 \cdot 7 \\
52 \cdot 4 \\
33 \cdot 3 \\
19 \cdot 0 \\
- \\
- \\
-\end{array}$ & $\begin{array}{r}42 \\
42 \\
42 \\
42 \\
42 \\
38 \\
32 \\
19 \\
3 \\
1 \\
0\end{array}$ & $\begin{array}{r}100 \cdot 0 \\
100 \cdot 0 \\
100 \cdot 0 \\
100 \cdot 0 \\
100 \cdot 0 \\
90 \cdot 5 \\
76 \cdot 2 \\
45 \cdot 2 \\
7 \cdot 1 \\
2 \cdot 4 \\
-\end{array}$ & $\begin{array}{r}25 \\
25 \\
25 \\
23 \\
17 \\
8 \\
3 \\
0 \\
0 \\
0 \\
0\end{array}$ & $\begin{array}{c}50 \cdot 0 \\
50.0 \\
50.0 \\
46.0 \\
34.0 \\
16.0 \\
6.0 \\
- \\
- \\
-\end{array}$ & $\begin{array}{r}42 \\
41 \\
38 \\
33 \\
20 \\
14 \\
8 \\
0 \\
0 \\
0 \\
0\end{array}$ & $\begin{array}{c}84 \cdot 0 \\
82 \cdot 0 \\
76 \cdot 0 \\
66 \cdot 0 \\
40 \cdot 0 \\
28 \cdot 0 \\
16 \cdot 0 \\
- \\
- \\
-\end{array}$ & $\begin{array}{r}38 \\
38 \\
37 \\
33 \\
24 \\
13 \\
4 \\
1 \\
0 \\
0 \\
0\end{array}$ & $\begin{array}{c}92.7 \\
92.7 \\
90 \cdot 3 \\
80.6 \\
58.5 \\
31.7 \\
9.8 \\
2.4 \\
- \\
-\end{array}$ & $\begin{array}{r}41 \\
41 \\
41 \\
40 \\
36 \\
27 \\
17 \\
7 \\
3 \\
0 \\
0\end{array}$ & $\begin{array}{r}100 \cdot 0 \\
100 \cdot 0 \\
100 \cdot 0 \\
97 \cdot 6 \\
87 \cdot 8 \\
65 \cdot 9 \\
41 \cdot 5 \\
17 \cdot 1 \\
7 \cdot 3 \\
- \\
-\end{array}$ \\
\hline
\end{tabular}

Columns marked $A$ indicate absolute numbers as well as percentages of cases reacting by normal agglutinins, or lacking these. Columns marked $I A$ contain the same indications as to incomplete antibodies.

(84 per cent.) and 41 positive rheumatic subjects (100 per cent.).

Fig. 1 shows the number and percentage of all subjects reacting positively, without regard to the titre of antibodies. After 14 days, $43 \cdot 1$ per cent. of the controls had developed normal agglutinins, as against 78.6 per cent. in the rheumatic group (significant at the 1 per cent. level). Incomplete antibodies were found in the sera of 60.8 per cent. of the controls and in all the rheumatic subjects (significant at the 1 per cent. level). After 19 days, 50 per cent. of the controls agglutinated as against 92.7 of the rheumatic subjects (significant at the 1 per cent. level). Reaction by incomplete antibodies at this stage was 84.0 per cent. in the control group and again 100 per cent. in the rheumatic group (significant, but only at the 5 per cent. level).

Fig. 2 (overleaf) shows the percentage of subjects reacting positively to different solutions of sera. The real values arrived at are given by the graph, and the line connecting them makes a logistic curve appropriately corresponding to these values. The maximum deviations of the curves are shown by the graph. In order to establish whether the ascertained differences in the course of the curves are significant these series of percentage values were compared as follows:

Let $x_{1}, x_{2}, \ldots x_{m}$ and $y_{1}, y_{2}, \ldots y_{n}$ be the ordered results of two random samples of sizes $m$ and $n$, taken from two populations with cumulative distribution functions $F_{m}(x)$ and $F_{n}(x)$.

Let $S_{m}(x)$ be the proportion of the $m$ observed values $x_{1}$ less than or equal to $x$, and $S_{n}(x)$ be the proportion of the $n$ observed values $y_{1}$ less than or equal to $x$.
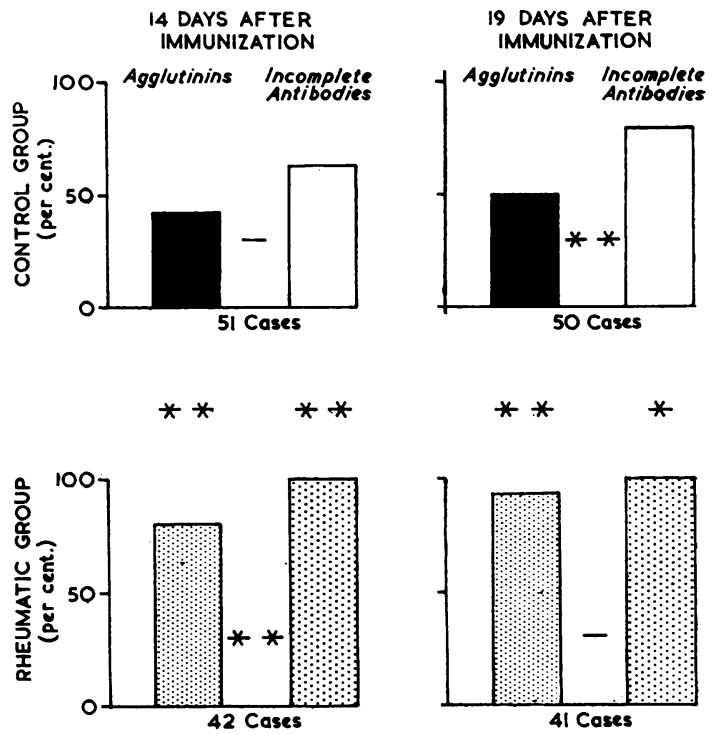

SIGNIFICANCE OF DIFFERENCE

- not signiticont

* significont ot 5 per cent. level ** significant ot I per cent. level

Fig. 1.-Percentage positive cases in control and rheumatic groups 14 and 19 days after immunization.

Then the expression $d=\max \left[S_{m}(x)-S_{n}(x)\right]$ can be used to test the hypothesis $F_{m}(x)=F(x)$, the limiting distribution $z=d \sqrt{\overline{m n} /(m+n)}$ being derived and tabled. In these Tables values $P\left(z \geqslant z_{o}\right)$ are given, i.e. the probability with which we can observe values of $z$ equal to or greater than our value $z_{o}$. 
TABLE II

COMPARISON OF AGGLUTININS (A) AND INCOMPLETE ANTIBODIES (IA) 14 AND 19 DAYS AFTER IMMUNIZATION OF CONTROLS AND RHEUMATIC SUBJECTS

\begin{tabular}{|c|c|c|c|c|c|c|c|c|}
\hline \multirow{2}{*}{$\begin{array}{l}\text { Valuation of maximum } \\
\text { difference of positive per- } \\
\text { centages in comparison with: } \\
\text { Blood Samples taken after . }\end{array}$} & \multicolumn{4}{|c|}{ All Cases } & \multicolumn{4}{|c|}{ All Positive Cases } \\
\hline & \multicolumn{2}{|c|}{14 days } & \multicolumn{2}{|c|}{19 days } & \multicolumn{2}{|c|}{14 days } & \multicolumn{2}{|c|}{19 days } \\
\hline$\ldots \quad \ldots$ & Control & Rheumatic & Control & Rheumatic & Control & Rheumatic & Control & Rheumatic \\
\hline$m ; n$ & $51 ; 51$ & $42 ; 42$ & $50 ; 50$ & $41 ; 41$ & $22 ; 31$ & $33 ; 42$ & $25 ; 42$ & $38 ; 41$ \\
\hline$d$ (per cent.) & $17 \cdot 7$ & $57 \cdot 1$ & $34 \cdot 0$ & $34 \cdot 1$ & $16 \cdot 7$ & $52 \cdot 0$ & $-20 \cdot 4$ & $31 \cdot 7$ \\
\hline$T$ & $\begin{array}{l}1: 4 \\
1: 8\end{array}$ & $\begin{array}{l}1: 256 \\
1: 512\end{array}$ & $\begin{array}{l}1: 4 \\
1: 8\end{array}$ & $1: 256$ & $1: 512$ & $1: 512$ & $1: 128$ & $1: 256$ \\
\hline$z_{0}$ & 0.89 & $2 \cdot 63$ & $1 \cdot 70$ & $1 \cdot 54$ & 0.60 & $2 \cdot 24$ & 0.81 & $1 \cdot 41$ \\
\hline$P\left(z \geqslant z_{0}\right)$ per cent. & $42 \cdot 1$ & $<0 \cdot 1$ & 0.7 & $1 \cdot 9$ & $87 \cdot 7$ & $<0 \cdot 1$ & $54 \cdot 4$ & $4 \cdot 0$ \\
\hline
\end{tabular}

$m=$ number of cases $A \quad n=$ number of cases $I A \quad z_{0}=d \cdot \sqrt{m \cdot n /(m+n)}$

$d=$ maximum percentual difference between number of reacting subjects in $I A$ and $A$. $T=$ titre in which the difference $d$ was reached.

The formula which was applied as a means for computing the values pictured by Fig. 2 has been expounded by Massey (1950), Wald and Wolfowitz (1939), Feller (1948), and other writers. It is a convenient method of estimating statistical data of this kind.

Table II shows primarily the differences between agglutinins and incomplete antibodies in the control group and in the rheumatic group as well as some contingent data. It must be read with constant reference to Table I.

The left-hand section of Table II gives the maximum differences between reacting subjects in incomplete antibodies $(I A)$ and agglutinins $(A)$ in percentages of all cases tested in the respective group and in the respective sample collection. This maximum difference $(d)$ can be found by subtracting the percentages indicated in Table $I$.

E.g.: The maximum difference between $A$ and $I A$ in the controls after 14 days (col. 1) is in titre $1: 4$ and $1: 8$ (line 3 ) in which the positive cases reach $43 \cdot 1$ per cent. for $A$ and 60.8 per cent. for $I A$ respectively, as indicated in Table I. The difference between these two percentages is $17 \cdot 7$ per cent. (line 2). Similarly, $d$ in the rheumatic group after 19 days (col. 4) is in titre 1.256 and is equal to 65.9 per cent $-31 \cdot 7$ per cent. $=34 \cdot 2$ per cent., etc. (The slight discrepancy of $0 \cdot 1$ per cent. against the value indicated in Table II is due to the rounding off of percentages necessitated by omission of the hundredths.)

The right-hand section of Table II gives the same maximum differences, but in comparison with the positive cases only, neglecting all negative cases. These differences cannot be simply read off from Table I, as in the left-hand section, but must be computed individually.
E.g.: Col. 5 shows that the $d$ in the control group after 14 days lies in the titre 1.512 and is equal to: $c$

$$
\begin{aligned}
\frac{8}{31}-\frac{2}{22} & =25.8 \text { per cent. }-9.1 \text { per cent. } \\
& =16.7 \text { per cent. }
\end{aligned}
$$

In these fractions the denominators are the numbers of positive cases in each titre, and the numerators are the numbers of all positive cases in the group collection, and type of antibody. Similarly, accordin to col. 8, the maximum difference in the rheumatic grou after 19 days is to be found in titre 1.256 and is equal to:

$$
\begin{aligned}
\frac{27}{41}-\frac{13}{38} & =65.9 \text { per cent. }-34 \cdot 2 \text { per cent. } \\
& =31.7 \text { per cent. }
\end{aligned}
$$

Table III (opposite) compares the control group and the rheumatic group as regards agglutinins and incomplete antibodies. The values in this Table were arrived at by a similar process to that used for Table II.

The calculated differences are represented in Figs 2 and 3 (opposite) by abscissae between corresponding curves. The degrees of significance are indicated by the number of crosses. Fig. 2 shows percentages of subjects who reacted in different titres positively by normal agglutinins as well as by incomplete antibodies 14 days after the immunization. It is apparent that the difference between normal agglutinins in both groups is significant, but only at the 5 per cent. level. There is no significant $\mathcal{N}$ difference between agglutinins and incomplete $N$ antibodies in the control group. On the other hand, N the difference between incomplete antibodies in controls and in rheumatic subjects is significant at the 1 per cent. level, the same as between the levels of $\stackrel{\circ}{=}$ incomplete antibodies and agglutinins in rheumatics. Fig. 3 shows analogous relations 19 days after the immunization. Although several differences are 
TABLE III

COMPARISON OF THE CONTROL GROUP AND THE RHEUMATIC GROUP 14 AND 19 DAYS AFTER IMMUNIZATION AS REGARDS AGGLUTININS ( $A$ ) AND INCOMPLETE ANTIBODIES (IA)

\begin{tabular}{|c|c|c|c|c|c|c|c|c|}
\hline \multirow{2}{*}{$\begin{array}{l}\text { Valuation of maximum } \\
\text { difference of positive percen- } \\
\text { tages in comparison with: } \\
\text { Blood Samples taken after . }\end{array}$} & \multicolumn{4}{|c|}{ All Cases } & \multicolumn{4}{|c|}{ All Positive Cases } \\
\hline & \multicolumn{2}{|c|}{14 days } & \multicolumn{2}{|c|}{19 days } & \multicolumn{2}{|c|}{14 days } & \multicolumn{2}{|c|}{19 days } \\
\hline $\begin{array}{llll}\text { Group } & \ldots & \ldots & \ldots\end{array}$ & $\mathbf{A}$ & IA & $\mathbf{A}$ & IA & $\mathbf{A}$ & IA & $\mathbf{A}$ & IA \\
\hline$m ; n$ & $51 ; 42$ & $51 ; 42$ & $50 ; 41$ & $50 ; 41$ & $22 ; 33$ & $31 ; 42$ & $25 ; 38$ & $42 ; 41$ \\
\hline$d$ (per cent.) & $37 \cdot 4$ & $70 \cdot 9$ & $42 \cdot 7$ & $47 \cdot 8$ & $25 \cdot 8$ & $58 \cdot 2$ & $-5 \cdot 2$ & $40 \cdot 2$ \\
\hline$T$ & $1: 32$ & $1: 256$ & $\begin{array}{l}1: 4 \\
1: 8 \\
1: 16\end{array}$ & $1: 128$ & $1: 128$ & $1: 256$ & $1: 64$ & $1: 128$ \\
\hline$z_{0}$ & $1 \cdot 80$ & $3 \cdot 40$ & $2 \cdot 03$ & $2 \cdot 27$ & 0.94 & $2 \cdot 47$ & $0 \cdot 20$ & $1 \cdot 83$ \\
\hline$P\left(z \geqslant z_{o}\right)$ per cent. & $0 \cdot 3$ & $<0 \cdot 1$ & $0 \cdot 1$ & $<0.1$ & $35 \cdot 3$ & $<0 \cdot 1$ & $>99.9$ & $0 \cdot 3$ \\
\hline
\end{tabular}

$m=$ number of cases in Control group $\quad n=$ number of cases in Rheumatic group $\quad z o=d . \sqrt{m . n /(m+n)}$ $d=$ maximum percentual difference between number of reacting subjects in Controls and $R$ heumatics. $T=$ titre in which difference $d$ was reached.

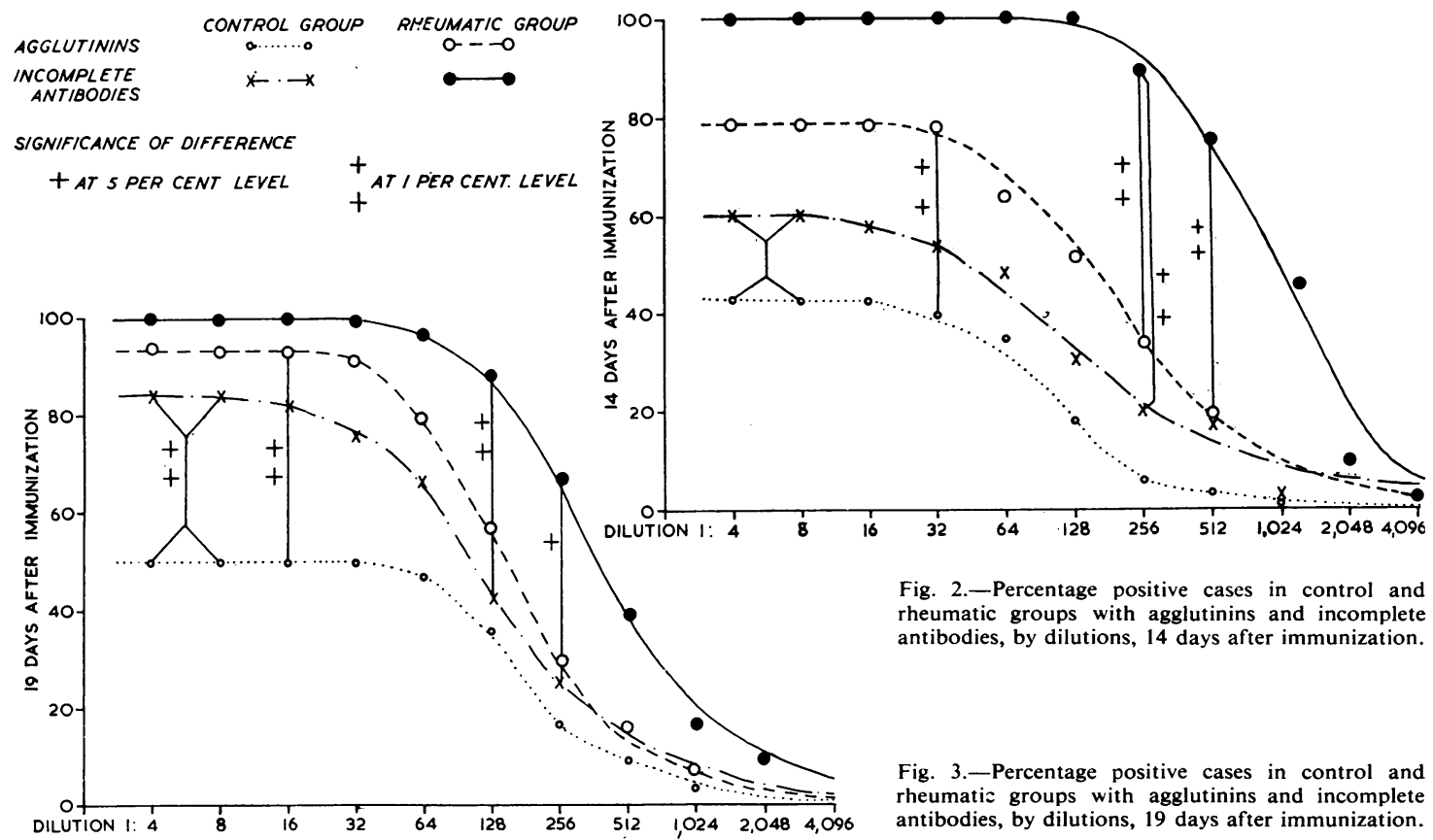

less significant as compared with Fig. 2, the significance between the curves of incomplete antibodies in both groups remains at the 1 per cent. level. The maximum difference between the numbers of reacting subjects in both groups is in titre 1.256 in both sample collections.

Figs 4 and 5 (overleaf) show the number of subjects who reacted by incomplete antibodies only up to the given titre, i.e. who were not positive above the level of the given titre after 14 and 19 days. It appears that after 14 days only four members of the rheumatic group reacted with a titre under $1 \cdot 256$. In the control group the first maximum of frequencies is in titre 1.64 ; the number of subjects reacting with higher titres then falls off, but it attains another maximum in titre 1.512. After 19 days the situation is analogous, but here both groups are already overlapping so that the differences between them 


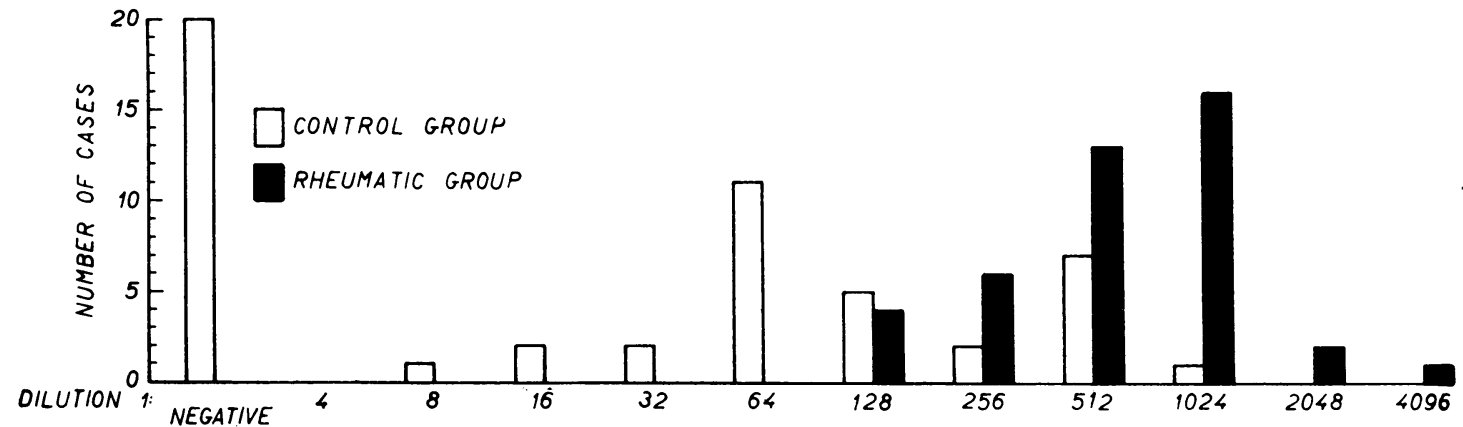

Fig. 4.-Number of positive cases in control and rheumatic groups, by dilutions, 14 days after immunization.

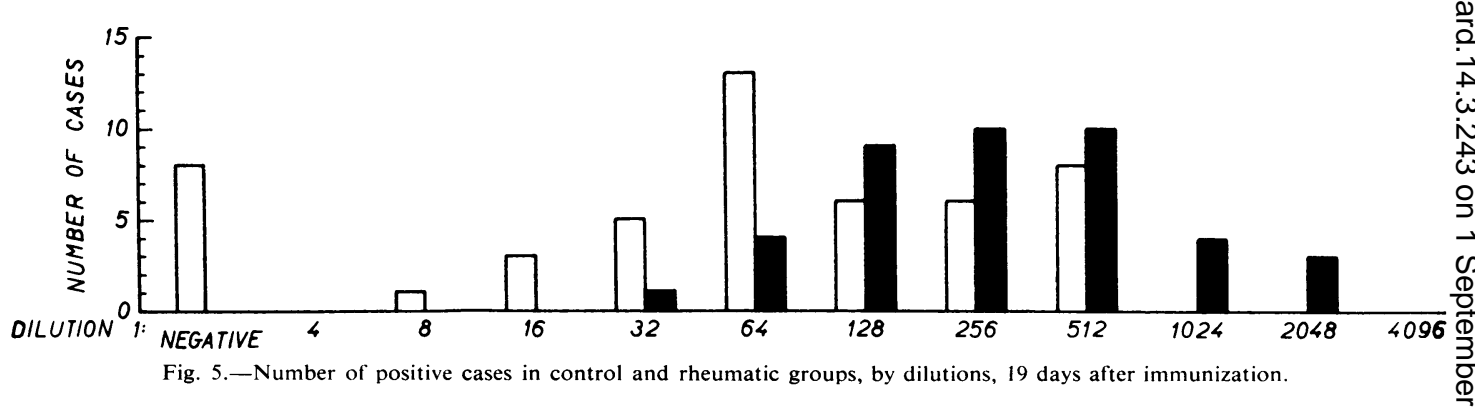

are not so significant. Nevertheless, it appears even here that the number of reacting subjects in the control group, after a certain decline in titre $1 \cdot 128$, surprisingly holds the same level in further dilutions, and only then begins to fall again.

There were ten controls and no rheumatic patients in whom, after 14 days, no higher titre was found by the antiglobulin serum than by agglutination. At this stage, there were eighteen controls and no rheumatic subjects in whom neither agglutinins nor incomplete antibodies were detected.

After 19 days, there were 21 controls and only six rheumatic patients in whom no higher titre was ascertained by means of the antiglobulin serum than by agglutination. At this stage, there were six controls and only one rheumatic patient who did not react at all, either by agglutination or by incomplete antibodies.

\section{Discussion}

The subjects investigated were very appropriate material for immunological tests. All were of the same age, lived in the same environment, and had the same food. The whole population was exposed to a fortuitous infection as a result of which a number contracted rheumatic fever. We may therefore consider the observed differences in the immunological responses to be real differences in the reactivity of the subjects. We do not feel entitled to decide whether these differences are due to heredity or to the influence of external conditions which weegect active before joining the said population. At any rate, we may call them the immunological com stitution of the investigated subjects.

From the methodological approach, the use of brucella bacteria appeared advantageous. Suspen- $\frac{\partial}{0}$ sions of this bacteria permit not only the investiga- $\stackrel{2}{2}$ tion of agglutination antibodies, but particularly the $\overrightarrow{\overrightarrow{0}}$ convenient investigation of incomplete antibodies 3 which are to be found regularly in natural contagions by this microbe (Griffitts, 1947; Renoux, 1950; Carrère and Renoux, 1951; D'Alessandro and Celano, 1950; Hall and Manion, 1953). Another reason for utilizing brucella was that antibodies do $\frac{5}{3}$ not usually occur in normal population in this age and vocational group. A further advantage was that this antigen did not provoke untoward reactions in the quantities used.

The results obtained after 5 and 10 days already $\frac{D}{O}$ showed convincingly that rheumatic subjects develop antibodies more readily, especially those of the $N$ incomplete type. Nevertheless, these results could not be made use of for statistical conclusions in N default of sufficiently high numbers.

The differences found after 14 days between the two groups did not appear quantitatively great wheno measured by normal agglutination reactions, but $\Phi$ were statistically significant. The exactitude of the ${ }^{+}$ ascertained relations is warranted by the relatively 
large number of investigated subjects. Creger and others (1951), though their results agree with ours, were not able to support their contention by convincing statistics. Nor could Miller and others (1953) or Quinn and others (1953) establish statistical significance of the difference between rheumatics and controls by means of normal antibodies.

On the other hand, the quantitative aspects of the development of incomplete antibodies differ fundamentally from those of normal antibodies. The difference in the levels shown in the graphs is statistically highly significant. Certain rheumatic subjects develop antibodies after as little as $\mathbf{8}$ days, and after 14 days 100 per cent. of them are positive as against 60 per cent. of the controls. Since no rheumatic subject was negative, it was possible to average the titre at $1 \cdot 792$, with no value under $1 \cdot 128$. 40 per cent. of the controls were negative. Statistical considerations, allowing only positive cases to be used for determining the average titre and omitting the negative cases, lead to a certain distortion of the picture; nevertheless, the average titre was between $1 \cdot 64$ and $1 \cdot 128$. The incidence of different titres in the control group (Figs 4 and 5) shows a greater dispersion of frequencies than that of the rheumatic group. The controls show a further and unexpected rise of incidence in the titres around 1.512. Further observations are necessary to determine whether these controls are in fact potential rheumatics, so far spared on unknown grounds, or allergics in whom a hitherto unproved analogous immunological reactivity may be assumed.

The control group included a certain number of subjects in whom incomplete antibodies could not be revealed by the method employed, as their titre did not exceed that of normal agglutinins. We have based our calculations on the surmise that incomplete antibodies were present in these subjects in the same titre as normal agglutinins. In other words, we have chosen the least favourable alternative for the demonstration of the increased development of incomplete antibodies in rheumatics in comparison with normal subjects.

On the strength of general immunological experience the antigen dosage may be assumed to influence the development of antibodies. In our tests we have chosen the dose nearly at random by applying McFarland's scale 4 as the standard of turbidity. On the basis of several preliminary tests we concluded that this quantity would lead to the formation of an exactly measurable amount of antibodies. Although the results are significant, it may be that the dose applied was too large, since a single injection produced antibodies in 80 per cent. of controls. Further tests will determine whether the difference between the two groups will increase with a lowering of the antigen dosage.

It is necessary to examine the exact role of an increased ability to develop antibodies in the pathogenesis of rheumatism. A number of communications show that incomplete antibodies are an important factor in the origin of allergic diseases (Coca and Grove, 1925; Miller and Campbell, 1947; Campbell and others, 1950; Sherman and others, 1950; Manack, 1951; Kuhns and Pappenheimer, 1952). Allergy has for a long time been suspected of partaking in the development of rheumatism. The present observations give further support to the hypothesis of the allergic origin of rheumatism, but it will be necessary to direct further research to trace the incomplete antibodies to streptococcus and tissue antigens which may develop naturally in rheumatic subjects. The question of the nature and the regulating mechanism of this altered reactivity of the host remains open.

\section{Summary}

A group of 42 convalescents from rheumatic fever and 51 healthy subjects were given a single inoculation of Brucella abortus bacteria in one dose. Titres of normal agglutinins and of incomplete antibodies were ascertained from blood samples taken after 5, 8, 14, and 19 days. The rheumatic subjects developed antibodies a little faster than normal persons. A small but statistically significant difference in the titres of normal agglutinins was found between the two groups, and a substantial difference appeared in the levels of incomplete antibodies. The inferences to be drawn from these quantitative and qualitative differences in reactivity are discussed, with reference to the pathogenesis of rheumatic fever.

The assistance rendered by J. Matějů of the District Centre of National Health, Litvínov, and by L. Symon, P. Jerie, A. Jeriová, and Z. Janda of the District Centre of National Health, Internes, Most, in organizing these investigations and in assembling materials is acknowledged with thanks.

\section{REFERENCES}

Aikawa, J. K. (1945). Ann. intern. med., 23, 969

Albertini, A. von (1933). Schweiz. med. Wschr., 14, 1177.

Alpern, D. E. (1934). "Summaries of Russian Reports of the Moscow Congress." Acta rheum. (Amst.), 6, No. 20/21, Appendix, p. 4. Congress." Acta rheum. (Amst.), 6, No. 20/21, Appendix, p. 4.
pbell, D. H., Cann, J. R., Friedman, T. B. and Brown, R. A. (1950). J., Allergy, 21, 519 .

Carrère, L., and Renoux, G. (1951). Ann. Inst. Pasteur, 80, 103.

Carrère, L., and Renoux, G. (1951). Ann. Inst. Pasteur, 80 ,

Coca, A. F., and Grove, E. F. (1925). J. Immunol., 10, 445. exp. Path., 26, 255.

Creger, W. P., Choy, S. H., and Rantz, L. A. (1951). J. Immunol., 66, 445.

D'Alessandro, G., and Celano, G. (1950). Boll. Ist. sierot. Mil.,

Feller, W. (1948). Ann. math. Statist., 10, 105.

Griffitts, J. J. (1947). Publ. Hith Rep., 62, 865 .

Grumbach, A. (1933). Schweiz. med. Wschr., 14, 1182.

Hall, W. H., and Manion, R. E. (1953). J. clin. Invest., 3296. 
Harris, T. N. (1948). Amer. J. Dis. Childh., 76, 411.

Klinge, F. (1933). "Der Rheumatismus", Ergebn. allg. Path. path.

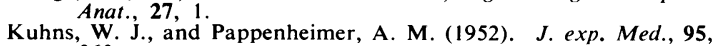
363 .

Marrack, J. R. (1951). Int. Arch. Allergy, 2, 264.

Massey, F. J. (1950). Ann. math. Statist., 21, 116, 440.

(1951). Ibid., 22, 125, 304.

Miller, H., and Campbell, D. H. (1947). Ann. Allergy 5, 236

Miller, J. M., Kibrick, S., and Massell, B. F. (1953). J. clin. Invest. 32, 691 .

Quinn, R. W., Seastone, V. C., and Dickie, H. A. (1953). J. Immunol., 70, 493

Rantz, L. A., Maroney, M., and Di Caprio, J. M. (1951). Arch. intern. Med., 87, 360 .

Renoux, G. (1950). Ann. Inst. Pasteur, 79, 232.

Rössle, R. (1933). Virchows Arch. path. Anat., 288, 780.

Sherman, W. B., Menzel, A. E. O., and Seebohm, P. M. (1950). J. exp. Med., 92, 191 .

Talalajew, V. T. (1933). Klin. Med. (Mosk.), 11, 992.

(1936). Acta rheum. (Amst.), 8, No. 30, p. 2

Wagner, V. (1954). Schweiz. Z. allg. Path. Bakt., 17, 94

Wald, A., and Wolfowitz, J. (1939). Ann. math. Statist., 19, 177.

Weintraud, W. (1913). Berl. klin. Wschr., 50, 1381.

Les agglutinines et les anticorps incomplets après une seule inoculation d'antigène chez des sujets normaux et rhumatisants

\section{RÉSUMÉ}

On a inoculé une seule dose de bacilles Brucella abortus à 42 convalescents de la maladie de Bouillaud et à 51 sujets normaux. On a determiné les titres des agglutinines normales et des anticorps incomplets dans le sang pris au bout de $5,8,14$ et 19 jours. Les rhumatisant produisaient des anticorps un peu plus vite que les sujetక normaux. On trouva une différence, petite mail. statistiquement significative, dans les titres des agglutin?? ines normales entre les deux groupes et une différence appréciable dans les taux des anticorps incomplets. Oß? discute la portée de ces différences quantitatives et qualie tatives de réactivité à propos de la pathogénie de lof maladie de Bouillaud.

Las aglutininas y los anticuerpos incompletos después d@ una sola inoculación de antígeno en sujetos normales reumáticos

SUMARIO

Se inoculó una sola dosis de bácilos Brucella abortus a 42 convalecientes de reumatismo poliarticular agud\&ు y a 51 sujetos sanos. Se determinaron los valores d aglutininas normales y de anticuerpos incompletos e. la sangre recogida al cabo de 5, 8, 14 y 19 días. Los. reumáticos produjeron anticuerpos algo más rapida mente que los sujetos sanos. Se observó una diferenciału pequeña pero estadisticamente significativa, en lof valores de las aglutininas normales entre los dos gruposu y una diferencia apreciable en las cifras de los ant cuerpos incompletos. Se discuten las implicaciones de estas diferencias cuantitativas y cualitativas de reactividad en relación con la patogenesis del reumatismo poliart to cular agudo. 